\title{
O PREGÃO ELETRÔNICO: UMA TENTATIVA DE SOLUÇÃO NA TRANSPARÊNCIA ATOS LICITATÓRIOS
}

THE ELECTRONIC PREGNANT: AN ATTEMPT TO SOLVE TRANSPARENCY INTO LICITATORY ACTS

\section{José Sérgio Saraiva ${ }^{1}$ Manoela Facho Inocênción Marcelo Toffano ${ }^{3}$}

ISSUE DOI: $10.21207 / 1983.4225 .596$

\section{RESUMO}

Este artigo vem tratar de um tema que engloba a área do Direito Administrativo, relacionado aos negócios celebrados pela Administração Pública com foco principal no pregão eletrônico, uma modalidade de licitação. Objetivando, demonstrar o surgimento da licitação no Brasil, qual o conceito e a finalidade da licitação e os principais princípios e legislações que a norteiam; apontar as demais modalidades de licitação que são a concorrência, tomada de preço, convite, leilão e Regime Diferenciado de Contratação - RDC e as principais diferenças entre estas modalidades em relação à mo-

\footnotetext{
${ }^{1}$ Doutorando em Direito pela FADISP (Faculdade Especializada em Direito), Mestre e Bacharel em Direito pela UNIFRAN (Universidade de Franca), Professor Universitário e Advogado.

${ }^{2}$ Graduanda em Direito pela Universidade de Franca.

${ }^{3}$ Doutorando em Direito pela FADISP (Faculdade Especializada em Direito), Mestre e Bacharel em Direito pela UNIFRAN (Universidade de Franca), Professor Universitário e Advogado.
} 
dalidade pregão, e principalmente demonstrar o que a inovadora modalidade pregão eletrônico veio a proporcionar para a Administração Pública, apontando suas características, seu procedimento, habilitação, documentos necessários, o pregoeiro, com o apoio de doutrinas, regulamentos e jurisprudências que tratam especificamente desta modalidade para destacar os pontos benéficos trazidos para a Administração Pública como a transparência, celeridade, economia, entre outros. Para a elaboração deste trabalho foi utilizado o método dedutivo-bibliográfico. Foram também elaborados os seguintes estudos: histórico, dogmático-jurídico e analítico-sintético.

Palavra-chave: Licitação. Pregão. Eletrônico.

\section{ABSTRACT}

This course conclusion work is dealing with a theme that encompasses the area of Administrative Law, related to business concluded by the public administration with main focus in electronic trading, a bidding mode. Aiming on setting out the creation of bidding in Brazil, its concepts, main goals and the main legislation surrounded around it; pointing out other forms of bidding such as the competition, online bid process, auction and Diferenciated Hiring Regime - DHR and the main differences between these topics and the online bid process topic, mainly focusing on demonstrating why the online bid process is so innovating and what it's capable of doing to the Public Administration, pointing out its characteristics, its procedures and license, the necessary documentation, the crier, with the support of the doctrine, regulations and law cases that look foward to online bid processing as well, to highlight the qualities brought up to the Public Administration with all the transparency, celerity, economy and others. To prepare this study we used the deductive-bibliographic method. Historical, dogmatic and legal and analytic-synthetic: the following studies were also developed.

Keyword: Bidding. Trading. Electronic.

\section{INTRODUÇÃO}

Quando o assunto é gastos públicos, os governos devem buscar a melhor forma de administrar, tendo como principais objetivos a economia, 
rapidez, transparência, o combate a corrupção e, contudo respeitando os preceitos da legislação.

E a Administração Pública, em grande parte, não consegue cumprir com tais objetivos, pois é considerada lenta, e vinculada a uma grande e rigorosa burocracia, deixando a desejar na efetividade de suas obrigações.

E o presente trabalho de conclusão de curso visa tratar do tema licitação na modalidade pregão eletrônico, uma ferramenta atual e inovadora da Administração Pública, em que o procedimento licitatório é realizado por meio de internet, quebrando as barreiras da rigorosa burocratização, permitindo uma maior flexibilidade na realização das compras, e atendendo aos principais objetivos acima citados.

Para se tratar diretamente sobre o pregão eletrônico, serão analisados primeiramente o surgimento, as características e os princípios que regem a licitação no Brasil; e todas as legislações que tratam diretamente ou subsidiariamente ao tema.

Uma breve analise das modalidades concorrência, tomada de preço, convite, leilão, concurso e o Regime Diferenciado de Contratação $\mathrm{RDC}$, apontando as principais diferenças entre a modalidade pregão.

Aprofundar na modalidade pregão eletrônico tratando detalhadamente quanto as suas características, ao seu procedimento, requisitos para a habilitação, o pregoeiro e os documentos necessários para que ocorra o processo licitatório, demonstrando o quanto esta modalidade acrescentou vantagens para a Administração Pública, quanto à economia dos gastos públicos, a credibilidade com os fornecedores e a sociedade pela transparência que mesma oferece e a celeridade nas contrações.

E estudos jurisprudenciais, colecionando julgados, para complementar o artigo. Para a elaboração deste trabalho foi utilizado o método dedutivo-bibliográfico. Foram também elaborados os seguintes estudos: histórico, dogmático-jurídico e analítico-sintético.

1 DA LICITAÇÃo

\subsection{CONCEITO E FINALIDADE}


Entende-se que licitação é um procedimento administrativo no qual a Administração Pública escolhe a proposta mais vantajosa para o contrato de seu interesse. Maria Sylvia Zanella Di Pietro utiliza parcialmente o conceito de José Roberto Dromi que define a licitação como:

$\mathrm{O}$ procedimento administrativo pelo qual um ente público, no exercício de sua função administrativa, abre a todos os interessados, que se sujeitem às condições fixadas no instrumento convocatório, a possibilidade de formularem propostas dentre as quais selecionará e aceitará a mais conveniente para a celebração de contrato ${ }^{4}$.

O autor Edmir Netto de Araújo cita em seu livro diversos conceitos sobre a licitação de autores renomados como José Cretella Junior:

Procedimento administrativo preliminar, mediante o qual a Administração, baseada em critérioprévio, seleciona entre várias propostas, referentes a compras, obras ou serviços, a que melhor atenda o interesse público a fim de celebrar contrato com o responsável pela proposta mais vantajosa ${ }^{5}$.

E ainda cita o conceito do autor Celso Antônio Bandeira de Melo, que define bem claramente o que é licitação:

Licitação é o procedimento administrativo pelo qual uma pessoa governamental, pretendendo alienar, adquirir ou locar bens, realizar obras ou serviços, segundo condições por ela estipuladas previamente, convoca interessados na apresentação de propostas, a fim de selecionar a que se revele mais conveniente em

${ }^{4}$ DI PIETRO, Maria Sylvia Zanella. Direito administrativo. 27. ed. São Paulo: Atlas, 2014. p. 373.

${ }^{5}$ ARAÚJO. Edmir Netto de.Curso de direito administrativo. 6. ed. São Paulo: Saraiva, 2013. Disponível em: <http://integrada.minhabiblioteca.com.br/books/9788502220362/page/553>. Acesso em: 9. abr. 2015. 
função de parâmetros antecipadamente estabelecidos e divulgados ${ }^{6}$.

Como finalidades, a licitação visa uma proposta mais vantajosa para a administração pública, e garantir a igualdade aos que visam um contrato com o Poder Público, devendo ser absoluta esta igualdade entre os interessados, visão esta de Hely Lopes Meirelles:

A finalidade da licitação é selecionar a proposta mais vantajosa para a administração, nem sempre se dá preeminência ao preço sobre os demais fatores, que podem ser preponderantes em determinados casos.

Por outro lado, visando a propiciar as mesmas oportunidades aos que desejam contratar com o Poder Publico, a licitação deverá garantir absoluta igualdade entre os interessados, princípio maior do qual se originam os demais princípios ${ }^{7}$.

São importantes também os dois objetivos que Toshio Mukai expõe em seu livro, pois aprofunda a finalidade que Hely Lopes Meirelles apresenta na citação acima, especificando com detalhes tais objetivos:

Assegurar que o poder público contrate obras, serviços e compras com o setor privado, obtendo a maior vantagem possível, no sentido de que o uso dos dinheiros públicos seja feito com parcimônia, em razão do princípio da indisponibilidade do interesse público; garantir que todos os membros da coletividade tenham iguais oportunidades de contratar com a administração, em razão do princípio

${ }^{6}$ ARAÚJO. Edmir Netto de. Curso de direito administrativo. 6. ed. São Paulo: Saraiva, 2013. VitalBook file. Disponível em: <http://integrada.minhabiblioteca.com.br/books/9788502220362/page/553>. Acesso em: 9abr. 2015.

${ }^{7}$ MEIRELLES, Hely Lopes. Licitação e contrato administrativo. 9. ed. São Paulo: Revistas dos Tribunais, 1990. p. 20. 
da igualdade dos administrados, relevante em direito administrativo ${ }^{8}$.

Assim, de forma bem objetiva, a licitação é o procedimento que visa à realização de contrato entre a administração pública e o licitante, em que a administração procura a proposta mais vantajosa e o desenvolvimento nacional, e os licitantes um direito de igualdade propiciando as mesmas oportunidades para todos.

\subsection{PRINCÍPIOS DA LICITAÇÃO PÚBLICA}

$\mathrm{O}$ art. 37, caput da CF, aponta de forma expressa cinco princípios norteadores da Administração Pública, sendo eles os princípios: da legalidade, impessoalidade, moralidade, publicidade e eficiência. E o princípio da Supremacia e Indisponibilidade do Interesse Público está de forma implícita, mas sempre de observância obrigatória.

Já os doutrinadores não são uniformes, sendo apontados os princípios do Procedimento Formal, Publicidade, Igualdade entre os licitantes, Vinculação ao Edital, Julgamento Objetivo, Probidade Administrativa, Adjudicação Compulsória.

O princípio da legalidade é de suma importância, pois o procedimento da licitação é vinculado à lei, as fases da licitação estão na Lei $\mathrm{n}^{\circ}$ 8.666/93.

O princípio da impessoalidade, expressa que aquele que realiza os procedimentos deve agir de forma objetiva ao que a norma de direito dispõe, sendo impessoal em qualquer ato realizado.

Quanto ao princípio da moralidade, este é tratado junto com o princípio da probidade, o autor define bem o conceito de moralidade, que significa "o procedimento terá de se desenrolar na conformidade de pa-

\footnotetext{
${ }^{8}$ MUKAI, Toshio. O novo estatuto jurídico das licitações e contratos públicos: comentário à Lei 8.666/93, com as alterações promovidas pela Lei 8.883/94. 3 . ed. São Paulo: Revista dos Tribunais, 1994. p.12.
} 
drões éticos prezáveis, o que impõe a administração e licitantes, um comportamento escorreito, liso, honesto, de parte a parte" trador, que ao cometer a improbidade administrativa deve ser punido com sanção como diz Hely Lopes Meirelles: "Suspensão dos direitos políticos, a perda da função pública, a indisponibilidade dos bens e o ressarcimento ao erário, na forma e gradação previstas em lei, sem prejuízo da ação penal cabível"10.

O princípio da publicidade é para que todos os interessados tenham conhecimento aos procedimentos, como também a fiscalização da sociedade quanto a sua legalidade.

O princípio da eficiência atua na licitação com a finalidade de buscar o melhor serviço com o menor preço, devendo os procedimentos ter o mínimo de falhas possíveis.

O princípio do procedimento formal impõe a todos os atos e fases da licitação prescrições legais, como trata o art. $4^{\circ}$, $\S$ único da lei 8.666/93: "O procedimento licitatório previsto nesta lei caracteriza ato administrativo formal, seja ele praticado em qualquer esfera da Administração Pública"11.

Quanto ao princípio da igualdade entre os licitantes visa a assegurar a igualdade a todos os licitantes de modo que ninguém seja discriminado ou favorecido por suas particularidades, e garantir a Administração a melhor escolha das propostas pelos interessados.

O princípio da vinculação ao edital é a base essencial da licitação, porque o edital é uma Lei interna da licitação, e tem que ser cumprido rigorosamente, pois tanto a Administração Pública quanto os interessados ao descumprir tais demandas gerará nulidade ao procedimento ou a desclassificação dos interessados.

Hely Lopes Meirelles é claro ao dizer que as regras do edital devem ser seguidas com rigor:

Estabelecidas as regras do certame, tornam-se inalteráveis para aquela licitação, durante todo o procedimento. Se não decorrer da licitação a

${ }^{9}$ MELLO, Celso Antônio Bandeira de. Curso de Direito Administrativo. 31. ed. São Paulo: Malheiros editores LTDA, 2014. p. 548.

${ }^{10}$ MEIRELLES, Hely Lopes. Direito administrativo brasileiro. 40. ed. São Paulo: Malheiros, 2014. p. 306.

${ }^{11}$ BRASIL. Lei 8.666/93. Lei das licitações.Art. $4^{\circ}$, § único. 
Administração verificar sua inviabilidade, deverá invalidá-la e reabri-la em novos moldes, mas enquanto vigente o edital ou convite, não poderá desviar-se de suas prescrições, quer quanto a tramitação, quer quanto ao julgamento ${ }^{12}$.

Também não deve ser entendido que tal princípio é absoluto, obstando a Administração e o Judiciário, respeitando o princípio da razoabilidade, para que rigor do edital não prejudique as finalidades da licitação.

O princípio do julgamento objetivo decorre dos princípios da legalidade e vinculação do edital, pois devem ser seguidos os critérios do da lei 8.666/93 e do edital para o julgamento das propostas, e o edital é uma lei, mesmo que interna. Busca afastar a discricionarismo dos julgadores. $\mathrm{O}$ art. 45 da Lei 8.666/93 diz claramente:

O julgamento das propostas será objetivo, devendo a Comissão de licitação ou o responsável pelo convite realizá-lo em conformidade com os tipos de licitação, os critérios previamente estabelecidos no ato convocatório e de acordo com os fatores exclusivamente nele referidos, de maneira a possibilitar sua aferição pelos licitantes e pelos órgãos de controle ${ }^{13}$.

Em relação ao princípio da adjudicação compulsória, "concluído o procedimento licitatório, seja atribuído o objeto da licitação ao vencedor do certame" ${ }^{\prime 14}$.Esta adjudicação é obrigatória, exceto se o licitante desistir do contrato ou passar do prazo. A compulsoriedade não permite uma nova licitação enquanto a mesma seja válida a adjudicação, e que o ganhador tem direito apenas a adjudicação. Nada impede a Administração de adiar

12 MEIRELLES, Hely Lopes. Direito administrativo brasileiro. 40. ed. São Paulo: Malheiros, 2014 p. 305.

${ }^{13}$ BRASIL. Lei 8.666/93. Lei das licitações. Art. 45.

${ }^{14}$ Disponível em: <http://www.ambito-juridico.com.br/site/index.php/?n_link=revista_artigos_leitura\&artigo_id=13610\&revista_caderno=4>. Acesso em $16 \mathrm{Set}$ 2015. 
ou anular o contrato, desde que tenha justa causa, só não é permitido contratar com outrem enquanto válida a adjudicação. É com a homologação da adjudicação que encerra os procedimentos e inicia o contrato.

\section{MODALIDADES DE LICITAÇÃO}

São 05 (cinco) as modalidades previstas na Lei 8.666/93, sendo elas concorrência, tomada de preço, convite, concurso e leilão. E o autor Celso Antônio Bandeira de Mello cita o art. $8^{\circ}$ da Lei quem diz: "é vedada a combinação delas, ou a adoção de outras" ${ }^{15}$, mas atualmente já existe a sexta modalidade que é o pregão. A Medida Provisória n ${ }^{\circ} 2.026$ de 04 de maio de 2000 crio a modalidade pregão, que foi convertida na Lei 10.520 de 17 de julho de 2002. E tem a Lei ${ }^{\circ} 12.465$ de 04 de agosto de 2011, que trata do Regime Diferenciado de Contratações - RDC.

A modalidade concorrência visa realizar uma licitação de ampla publicidade, assegurando a participação de todos os interessados, desde que preenchidos os requisitos no edital, como trata o art. $22, \S 1^{\circ}$ da Lei 8.666/93. Hely Lopes Meirelles diz que "é a modalidade de licitação própria para contratos de grande valor" 16 .

Esta modalidade é obrigatória na contratação de serviços, obras e compras de Engenharia e outros serviços comuns, na compra e alienação de bens imóveis e concessão de direito real e uso. O mesmo se aplica quando a licitação é internacional.

As características desta modalidade são ampla publicidade e a universalidade. A ampla publicidade é para assegurar publicação do aviso do edital, a divulgação da concorrência. A publicação deve ser feita pelo Diário Oficial da União quando o órgão for a Administração Pública Federal, no Diário Oficial do Estado ou Distrito Federal, quando o órgão for a Administração Estadual, Municipale Distrito Federal, além de todos os outros meios como jornais de grande circulação. A publicação será com no mínimo de 30 (trinta) dias, exceto quando o tipo for melhor técnica ou técnica e preço, sendo o prazo de 45 (quarenta e cinco) dias, conforme o art.

${ }^{15}$ MELLO, Celso Antônio Bandeira de. Curso de Direito Administrativo. 31. ed. São Paulo: Malheiros, 2014. p. 567.

${ }^{16}$ MEIRELLES, Hely Lopes. Direito administrativo brasileiro. 40. ed. São Paulo: Malheiros, 2014. p. 360. 
21, $\S 2^{\circ}$, incisos I e II da Lei 8.666/93.A universalidade é a possibilidade de todos os interessados participarem da licitação desde que preenchidos todos os requisitos exigidos no edital.

Seu procedimento é complexo, seguindo as seguintes fases: edital, habilitação, classificação, homologação e adjudicação.

A modalidade tomada de preços é para os interessados previamente cadastrados ou para os que preencham os requisitos para cadastramento até o $3^{\circ}$ dia que antecede a entrega da proposta, sempre sendo observada a necessária qualificação, conforme o art. $22, \S 2^{\circ}$ e 36 da Lei $8.66 / 93$.

Quanto à ampla publicação se aplica o mesmo que na concorrência, com diferença em relação ao prazo de 45 (quarenta e cinco) dias na concorrência e 15 (quinze) na tomada de preço conforme o art. $21, \S 2^{\circ}$, inciso II da Lei 8.666/93.

Esta modalidade é voltada para as contratações de obras, serviços, e compras, desde que respeitados os limites estabelecidos pela lei, segundo o art. 23, I, alínea "b".

$\mathrm{O}$ procedimento da tomada de preço segue as mesmas fases da concorrência, tendo algumas diferenças, quanto a prazos, a exigência do cadastro.

A modalidade convite é a mais simples dentre todas as outras modalidades. Esta voltada para licitações de pequeno valor. Pode ser contratada obras, serviços e compras. Os licitantes são convocados por meio de carta-convite.

A carta convite deve ser direcionada a pelo menos 3 (três) interessados, dentro de 3 (três) dias, sendo os interessados cadastrados ou não. E a resposta deve ser apresentada dentro do prazo de 5 (cinco) dias úteis, conforme art. $21, \S 2^{\circ}$, inciso IV da Lei 8.666/93.

Com a entrega da proposta, o procedimento segue a seguinte ordem: classificação, adjudicação e homologação.

A modalidade concurso é voltada para trabalho técnico, científico ou artístico. É mediante prêmio ou remuneração, conforme art. $22, \S 4^{\circ}$ da Lei 8.666/93.

Quanto à publicidade, é por meio de edital na imprensa oficial e particular, o prazo é de 45 (quarenta e cinco) dias, conforme os arts. $22, \S$ $4^{\circ}$ e $21, \S 2^{\circ}$, inciso I, alínea "a" da Lei 8.666/93. 
E se o concurso for voltado para projetos, critérios e condições constarão no regulamento do concurso, como dispõe o art. $52, \S 2^{\circ}$ da Lei 8.666/93. O autor Elisson Pereira da Costa cita que o regulamento deve indicar "a qualificação exigida dos participantes; as diretrizes e a forma de apresentação do trabalho; e as condições de realização do concurso e os prêmios a serem concedidos"17.

Com a classificação e o pagamento dos prêmios, não gera direito de contrato com a administração, realizando nova licitação para execução do projeto escolhido.

A modalidade leilão é voltada para venda de bens móveis e semoventes, conforme art. $22, \S 5^{\circ}$ e 53 , em casos especiais na venda de imóveis, conforme o art. 19, inciso III, todos da Lei 8.666/93, pois a venda de imóveis é através da concorrência.

Há dois tipos de leilão, sendo eles o comum com leiloeiro oficial, e o administrativo. É a legislação federal que rege o leilão comum, como também pela administração, já no administrativo é regulado pelas normas da Administração interessada, para "venda de mercadorias apreendidas como contrabando, ou abandonadas nas alfândegas, nos armazéns ferroviários ou nas repartições públicas em geral"18.

O leilão é um ato negocial instantâneo, não dependente de contrato formal. O bem no leilão é apregoado, são verbais os lances. E por se tratar de alienação de bens móveis, o art. 17 da Lei 8.666/93 dever ser observado quanto à avaliação do bem, disposição aos interessados para dar publicidade, edital indicando local, data e hora em que ocorrera o leilão do bem apregoado.

A modalidade de licitação em regime diferenciado de contratação - RDC, é utilizada exclusivamente nas licitações e contratos voltados para:

Jogos Olímpicos e Paraolímpicos de 2016;

${ }^{17}$ COSTA, Elisson Pereira da. Coleção saberes do direito ; v. 33 - Direito administrativo III : bens públicos, licitação, contratos administrativos e intervenção do Estado na propriedade privada, $1^{a}$ Edição. Saraiva, 2012. Disponível em: <http://integrada.minhabiblioteca.com.br/books/9788502178656/page/48>. Acesso em: 6 Ago 2015.

${ }^{18}$ MEIRELLES, Hely Lopes. Direito administrativo brasileiro. 40. ed. São Paulo: Malheiros, 2014. p. 371. 
Copa das Confederações da Federação Internacional de Futebol Associação - FIFA 2013 e Copa do Mundo FIFA 2014;

Obras de infraestrutura e de contratação de serviços para os aeroportos das capitais dos Estados da Federação distantes até $350 \mathrm{~km}$ das cidades sedes dos mundiais citados acima ${ }^{19}$.

Portanto, esta modalidade é utilizada em casos específicos, com duração limitada, encerrando depois de concluso os eventos. É regulada pela Lei 12.462 de 04 de Agosto de 2011, e ampliada para outros contratos como para o regime às ações integrantes do Programa de Aceleração do Crescimento - PAC, realização de obras e serviços de engenharia no âmbito dos sistemas de ensino público e no âmbito do Sistema Único de Saúde - SUS, e também ser utilizado nos contratos da Companhia Nacional de Abastecimento - CONAB.

No procedimento há uma inversão nas fases, em que a habilitação é após a abertura das propostas, sendo que só a documentação do vencedor será verificada.

A modalidade pregão esta direcionada para aquisição de bens e serviços comuns. É na Lei 10.520 de 17 de julho de 2002 que esta modalidade esta regulada, mas sempre observando a lei 8.666/93.

A norma legal diz que bens e serviços comuns são "aqueles cujos padrões de desempenho e qualidade possam ser objetivamente definidos pelo edital, por meio de especificações usuais no mercado" ${ }^{20}$. Mas o que caracteriza bens e serviços é o poder de substituição de um por outro desde que com a mesma eficiência e qualidade.

O procedimento no pregão é abreviado e de julgamento objetivo, pois visa sempre o menor preço. A fase de habilitação e julgamento é inversa. O procedimento é composto por uma fase interna, conhecida preparatória, e outra chamada fase externa.

${ }^{19}$ COSTA, Elisson Pereira da. Coleção saberes do direito ; v. 33 - Direito administrativo III : bens públicos, licitação, contratos administrativos e intervenção do Estado na propriedade privada, $1^{a}$ Edição. Saraiva, 2012. Disponível em: <http://integrada.minhabiblioteca.com.br/books/9788502178656/page/70>. Acesso em: 11 Ago 2015.

${ }^{20}$ MEIRELLES, Hely Lopes. Direito administrativo brasileiro. 40. ed. São Paulo: Malheiros, 2014. p. 370. 
$\mathrm{Na}$ fase preparatória, antes da abertura do procedimento, é exigido que justifique o motivo de contratação, definição do objeto, habilitação e critérios para ser aceita a proposta e penalidades, como exige o art. $3^{\circ}$ da Lei 10.520/02.

Já na fase externa, os atos que ocorreram no procedimento: "edital, julgamento e classificação, habilitação do licitante vencedor, adjudicação e homologação" 21 , tudo descrito no art. $4^{\circ}$, em seus 23 incisos da Lei $10.520 / 02$. O pregoeiro e a equipe de apoio serão designados para receber as propostas e os lances, verificar a aceitação, classificação, habilitação e adjudicação do objeto ao vencedor, conforme o art. $3^{\circ}$, IV da Lei $10.520 / 02$. E finalizando o procedimento com a homologação, o vencedor assinara o contrato dentro do prazo estipulado no edital.

Importante apontar a distinção entre a modalidade pregão e as demais modalidades.

A complexidade no procedimento da modalidade pregão é muito mais célere em relação às demais modalidades. $\mathrm{O}$ as fases são inversas, em que ocorre primeiro o julgamento das propostas, sendo aberto o envelope somente do candidato vencedor, o que não ocorre nas outras modalidades.

Quanto ao valor no pregão não tem limites, os candidatos podem dar lances, até que chegue a um menor preço favorável para a administração pública. No pregão, em caso de irregularidades na documentação do candidato vencedor, não gera a desclassificação instantânea, podendo ser sanadas. Os lances são verbais durante a sessão, enquanto nas demais é obrigatório ser escrito.

\section{PREGÃo ELETRÔNICO}

A modalidade pregão eletrônico, é realizado por meio de tecnologia da informação, comunicação por meio da internet. "O sistema eletrônico será dotado de recursos de criptografia e de autenticação que garantam condições de segurança em todas as etapas do certame" 22 .

${ }^{21}$ DI PIETRO, Maria Sylvia Zanella. Direito administrativo. 27. ed. São Paulo: Atlas, 2014. p. 437.

${ }^{22}$ COSTA, Elisson Pereira da. Coleção saberes do direito ; v. 33 - Direito administrativo III : bens públicos, licitação, contratos administrativos e intervenção do Estado na propriedade privada, $1^{a}$ Edição. Saraiva, 2012. Disponível em: 
O pregão eletrônico tem como princípios básicos: o da legalidade, pois norteia os atos administrativos; da impessoalidade e moralidade, que visam evitar fraudes e artimanhas que impeça a competitividade no certame; da igualdade, para não limitar a participação do licitante no certame; da probidade administrativa, que faz com que o pregoeiro tenha boafé e idoneidade, cabendo sanção ao agente; da vinculação ao instrumento convocatório, que obriga a seguir todas as normas e condições do edital para a realização do certame, do julgamento objetivo, que deve seguir os critérios do edital, para evitar qualquer decisão subjetiva; da competitividade, para maior acesso de licitantes no certame.

E destacando como principais princípios o da publicidade (transparência), eficiência (celeridade), sendo disponível o acesso por qualquer cidadão e de forma ágil, gerando economia tanto para a administração pública e os licitantes, estando dispostos tais princípios no art. $5^{\circ}$ do Decreto $\mathrm{n}^{\circ} 5.450 / 2005$.

É regulamentado pela Lei ${ }^{\circ} 10.520$ de 17 de julho de 2002, Decreto $\mathrm{n}^{\circ} 5.540$ de 31 de Maio de 2005 e a Lei $\mathrm{n}^{\circ} 8.666$ de 21 de Junho de 1993. Utilizado na contratação de bens e serviços comuns, em que a lei $\mathrm{n}^{\circ}$ $10.520 / 2002$ define bens e serviços, o Decreto $\mathrm{n}^{\circ} 5.450 / 2005$, determina a obrigatoriedade do pregão para aquisição de bens e serviços comuns no âmbito da União e todos controlados pela mesma de forma direta ou indiretamente, segundo art. $4^{\circ}, \S 1^{\circ}$ e $2^{\circ}$. "E não se aplica na contratação de obras de engenharia, locações imobiliárias e alienação em geral"23.

O pregão eletrônico ocorre à distância, em sessão pública, por meio da internet, e que esta disposto no art. $2^{\circ}$ do Decreto 5.450/2005.

No edital, conterá critérios objetivos que permitam aferir o menor preço, prazos para a execução do contrato e fornecimento, especificações técnicas, parâmetros mínimos de desemprenho e de qualidade, conforme art. $2^{\circ}, \S 2^{\circ}$ do Decreto 5.450/2005.

$<$ http://integrada.minhabiblioteca.com.br/books/9788502178656/page/50>. Acesso em: 27 Jul 2015.

${ }^{23}$ COSTA, Elisson Pereira da.Coleção saberes do direito ; v. 33 - Direito administrativo III : bens públicos, licitação, contratos administrativos e intervenção do Estado na propriedade privada, $1^{\text {a }}$ Edição. Saraiva, 2012. VitalBook file. Disponível em: $<$ http://integrada.minhabiblioteca.com.br/books/9788502178656/page/51>. Acesso em: 1 Ago 2015. 
É conduzido pelo órgão ou entidade promotora da licitação, com apoio técnico e operacional da Secretaria de Logística e Tecnologia da Informação do Ministério do Planejamento (SLTI), Orçamento e Gestão, que atuará como provedor do sistema eletrônico para os órgãos integrantes do Sistema de Serviços Gerais (SISG).

E se o pregão eletrônico for promovido pelo órgão integrante do SISG, o credenciamento, como a manutenção, depende de registro no Sistema de Cadastramento Unificado de Fornecedores (SICAF).

É através de chave de identificação que participa de todas as licitações, exceto em caso de cancelamentos pelo credenciado ou descadastramento perante o SICAF, conforme o art. $2^{\circ}$, $\S 3^{\circ}$ do Decreto 5.450/2005, e o licitante assume todas as responsabilidades desta chave.

Como no pregão presencial, o eletrônico tem duas fases, uma interna, mais conhecida como preparatória e uma externa.

$\mathrm{Na}$ fase preparatória, ocorre elaboração de forma precisa, suficiente e clara do termo de referência do órgão requisitante; aprovação do termo pela autoridade competente e justificativa da necessidade da contratação; definir todas as exigências de habilitação, sanções, prazos e condições relevantes para a celebração, execução de contrato e atendimento das necessidades da administração; e designação de um pregoeiro e sua equipe de apoio, como esta disposto no art. $9^{\circ}$, incisos I, II, III, IV e V do Decreto $\mathrm{n}^{\circ} 5.450 / 2005$.

A autoridade competente tem que fundamentar o motivo da aprovação do termo de referência e da necessidade de contratação, conforme o $\S 1^{\circ}$ do art. $9^{\circ}$.

Aos servidores do órgão ou entidade que promover a licitação ou integrante do SISG, recairão todas as designações do pregoeiro e da equipe de apoio, conforme art. 10.

A equipe de apoio deverá ser integrada por servidores da administração pública, de preferência aos servidores que são permanentes ao órgão ou entidade promotora da licitação, conforme $\S 1^{\circ}$ do art. 10. Poderão os militares, no âmbito do Ministério da Defesa atuar como pregoeiro e membro da equipe de apoio, segundo o $\S 2^{\circ}$ do art. 10.

E a designação do pregoeiro, pode ocorrer pelo período de um ano, sendo permitidas reconduções, ficando a critério da autoridade competente; conforme os $\S 3^{\circ}$ e $4^{\circ}$ do art. 10. 
A fase externa inicia com o art. 17 do Decreto 5.450/2005, que trata da convocação dos interessados através de publicação de aviso, tendo para cada valor da contratação uma forma de divulgação.

Benedicto de Tolosa Filho cita as formas de publicação em seu livro:

1 - Diário Oficial da União e por meio eletrônico, na Internet, para bens e serviços de valores estimados em até $\mathrm{R} \$ 160.000,00$.

2 - Diário Oficial da União, por meio eletrônico, na Internet e em jornal de grande circulação local, para bens e serviços de valores estimados acima de R\$ $160.000,00$ até $\mathrm{R} \$ 650.000,00$.

3 - Diário Oficial da União, por meio eletrônico, na Internet e jornal de grande circulação regional ou nacional, para bens e serviços de valores estimados acima de $\mathrm{R} \$ 650.000,00^{24}$.

Aos que participam do SISG, o edital é disponibilizado no Portal de Compras do Governo Federal - COMPRASNET, no site www.comprasnet.gov.br.

O aviso do edital deverá ser precisa, suficiente e clara em relação ao objeto; local, dia e horários indicados; o endereço eletrônico onde será a sessão pública com a data e a hora da realização, isto é exposto no $\S 2^{\circ}$ do art. 17.

O prazo para as propostas serem apresentadas é de no mínimo oito dias, e é contado da última publicação do edital, "excluído o dia da publicação e incluído o dia do vencimento" ${ }^{25}$, conforme o art. 110 da Lei 8.666/93. O mesmo dispõe o $§ 4^{\circ}$ do art. 17.

\footnotetext{
${ }^{24}$ TOLOSA FILHO,Benedicto de. Pregão - Uma Nova Modalidade de Licitação, $5^{\mathrm{a}}$ edição. Forense, 2012. Disponível em: <http://integrada.minhabiblioteca.com.br/books/978-85-309-4397-4/page/60>. Acesso em: 06Ago 2015.

${ }^{25}$ BRASIL. Lei 8.666/93. Lei das licitações.Art. 110.
} 
Benedicto de Tolosa Filho faz uma ressalva, "muito embora a lei fixe em 8 dias úteis no mínimo, deverá ser ampliado dependendo da complexidade para elaboração das propostas" 26 .

O edital pode ser impugnado por qualquer pessoa (física ou jurídica), até dois dias antes da data de realização da sessão pública; é o pregoeiro quem decide a impugnação e tem vinte e quatro horas para decidir; e se acolhida à impugnação, uma nova data será definida e publicada novamente, estão tudo disposto no art. 18 e seus parágrafos.

Para dúvidas e esclarecimentos, o prazo é de três dias antes da data da abertura da sessão pública; e qualquer modificação no edital, tem que ser novamente publicado, no mesmo meio da publicação anterior, tendo que reabrir um novo prazo para as propostas, como está previsto nos arts. 19 e 20.

Divulgado o edital, as propostas deverão ser encaminhas pelos licitantes, contendo a descrição do objeto, preço e anexos, respeitando a data e à hora marcada para abertura da sessão, que sendo iniciada encerra automaticamente o recebimento das propostas.O pregoeiro dará início à sessão pública no horário previsto no edital, por meio de sua chave de acesso e senha, verificando se as propostas estão em conformidade com os requisitos do edital, desclassificando as que não preencheram os requisitos, fundamentando os motivos da desclassificação, conforme art. 22.

A verificação das propostas dita no art. 22 é por meio eletrônico, mas Marçal Justen Filho diz que ela também ocorre por uma fiscalização externa:

O recebimento das propostas e seu exame se fará no âmbito do sistema eletrônico. Isso não pode significar que o pregoeiro e a equipe de apoio realizarão o exame e seleção sem qualquer espécie de fiscalização externa. Devem existir instrumentos que assegurem a impossibilidade de: a) recebimento de propostas antes ou depois do prazo; b) o conhecimento, inclusive da Administração Pública, acerca do conteúdo das propostas antes de encerrado o prazo previsto; e c)

\footnotetext{
${ }^{26}$ TOLOSA FILHO, Benedicto de. Pregão - Uma Nova Modalidade de Licitação, $5^{\mathrm{a}}$ edição. Forense, 2012. Disponível em: <http://integrada.minhabiblioteca.com.br/books/978-85-309-4397-4/page/62>. Acesso em: 06Ago 2015.
} 
modificação superveniente dos termos das propostas, mesmo para suprir eventuais defeitos ou equívocos. ${ }^{27}$.

As propostas classificadas pelo pregoeiro são automaticamente ordenadas pelo sistema, e apenas estas participarão da fase de lance, conforme o art. 23. Classificadas as propostas, inicia a fase competitiva, em que os licitantes darão seus lances pelo sistema eletrônico. $\mathrm{O}$ autor Gustavo Rodrigues Amorim resume bem o art. 24 nos parágrafos $1^{\circ}$ ao $5^{\circ}$ :

Os licitantes devem oferecer lances sempre menores que o último que aparece na tela do sistema. Os licitantes que conecta na internet no endereço eletrônico indicado em edital e estão aptos para oferecer propostas cada vez menores, são identificados por pseudônimos, ou seja, não reconhecem os outros licitantes, cujas propostas aparecem na tela do sistema com isso possibilitando evitar acordos entre $\mathrm{eles}^{28}$.

O pregoeiro quem decide o encerramento da etapa dos lances, e o sistema eletrônico avisa sobre o fechamento dos lances aos licitantes dentro do período de trinta minutos, ao qual é encerrado automaticamente. E o pregoeiro poderá encaminhar contraproposta ao licitante que teve melhor lance apresentado, segundo os parágrafos $7^{\circ}$ e $8^{\circ}$.

Benedicto de Tolosa Filho trata da regra do art. 44 da lei complementar $n^{\circ} 123 / 06$, após os parágrafos $7^{\circ}$ e $8^{\circ}$ :

Em seguida, o pregoeiro deve aplicar a regra do art. 44 da Lei Complementar n. 123/06, identificando as proponentes que se enquadrem na categoria de microempresa ou de empresa de pequeno porte, cujos preços estejam iguais ou superiores em até $5 \%$ com relação à proposta de menor valor, apresentada por licitante sem essas características, em face do

${ }^{27}$ JUSTEN FILHO, Marçal. Pregão: (comentários à legislação do pregão comum e eletrônico). $1^{\circ}$. ed. São Paulo: Dialética, 2001. p. 213.

${ }^{28}$ AMORIM, Gustavo Rodrigues. Licitação Eletrônica - Pregão Eletrônico: o marco normativo da tecnologia da informação nos contratos públicos. $1^{\circ}$. ed. Leme/SP: Anhanguera Editora Jurídica, 2010. p. 256. 
disposto no $\S 20$ do art. 44 da Lei Complementar invocada $^{29}$.

O autor faz esse levantamento, pois o $\S$ único do art. 11 do Decreto n 6.204 de 05 de Setembro de 2007 diz: "A identificação das microempresas ou empresas de pequeno porte na sessão pública do pregão eletrônico só deve ocorrer após o encerramento dos lances, de modo a dificultar a possibilidade de conluio ou fraude no procedimento"30.

Pode ocorrer de o pregoeiro desconectar-se da sessão, se passar mais de dez minutos a desconexão, a sessão será suspensa sem prejuízo aos licitantes, e reiniciará após comunicar todos os licitantes, conforme os parágrafos 10 e 11 .

Com o encerramento da etapa de lances, a proposta que ficou em primeiro lugar será examinada pelo pregoeiro, em relação ao preço estimado e a habilitação, como dispõe o art. 25, caput.

A habilitação é verificada por meio do SICAF, quando forem realizados por órgãos integrantes do SISG. Na falta de documentos exigidos ou haver necessidades de anexo, deverão ser enviados via fax dentro do prazo definido no edital, e depois enviado o documentos e anexos originais, conforme os parágrafos $1^{\circ}, 2^{\circ}$ e $3^{\circ}$ do art. 25 .

Caso a proposta não for aceita e o licitante não corresponder com a habilitação, a proposta subsequente será analisada pelo pregoeiro e assim sucessivamente até que encontre uma proposta que atenda o edital, segundo o $\S 5^{\circ}$ do art. 25. Marçal Justen Filho divide em duas formas quanto à não aceitação da habilitação: "poderá haver omissão do licitante e poderá ocorrer defeito na documentação propriamente dita" 31 , neste segundo caso pode ser enviado por via fax como mencionada no parágrafo anterior.

No caso do pregão realizado para o sistema de registro de preços, a proposta vencedora não satisfazer ao estimado para contratação, poderá ser convocados os outros licitantes na ordem da classificação para chegar ao estimado, observado o preço da proposta vencedora, como dispõe o $\S$

${ }^{29}$ TOLOSA FILHO, Benedicto de. Pregão - Uma Nova Modalidade de Licitação, $5^{\mathrm{a}}$ edição. Forense, 2012. Disponível em: <http://integrada.minhabiblioteca.com.br/books/978-85-309-4397-4/page/62>. Acesso em: 12 Ago 2015.

30 Disponível em: <http://www.planalto.gov.br/ccivil_03/_Ato20072010/2007/Decreto/D6204.htm>. Acesso em: 12 de Ago 2015.

${ }^{31}$ JUSTEN FILHO, Marçal. Pregão: (comentários à legislação do pregão comum e eletrônico). $1^{\circ}$. ed. São Paulo: Dialética, 2001. p. 228. 
$7^{\circ}$. Gustavo Rodrigues Amorim explica o que é este sistema de registro de preço:

O sistema de registro de preço trata-se de um procedimento de licitação em que se escolhem licitantes para fornecimento futuro de bens e serviços, bem para o órgão que dirigiu o procedimento bem como aos que aderiram a ele, e podem utilizar-se do instrumento final, a Ata de Registro de Preços, para escolherem os fornecedores para as suas necessidades ${ }^{32}$.

E outros procedimentos relacionados ao sistema de registro de preços, aplica-se a Lei específica 8.666/93.

O licitante será declarado vencedor, ao atender as exigências fixadas no edital, conforme o $\S 9^{\circ}$.

$\mathrm{O}$ art. 26 e seus parágrafos tratam da fase recursal, em que os interessados manifestam suas intenções de recorrer, em campo próprio do sistema, tendo um prazo de três dias para apresentar suas razões. Os outros licitantes ao serem intimados têm prazo igual, contados do termino do prazo do recorrente para apresentar suas contrarrazões. E decairá do direito o licitante que não se manifestar de forma imediata e motivada da intenção de recorrer, sendo autorizado o pregoeiro a adjudicação do objeto ao licitante vencedor, segundo o $\S 1^{\circ}$.

Se as razões recursais forem acolhidas, apenas os atos viciados serão invalidados. E o pregoeiro no julgamento da habilitação e das propostas, poderá reparar as falhas e erros de modo que não altere a substância da proposta, dos documentos e a validade jurídica, com despacho fundamentado e registrado em ata disponível a todos, tendo validade e eficácia para habilitação e classificação, como dispõe os parágrafos $2^{\circ}$ e $3^{\circ}$.

Estando os recursos decididos e todos os atos praticados com regularidade, cabe a autoridade competente a adjudicação do objeto e homologar o procedimento licitatório, segundo o caput do art. 27. Entende-se

\footnotetext{
32 AMORIM, Gustavo Rodrigues. Licitação Eletrônica - Pregão Eletrônico: o marco normativo da tecnologia da informação nos contratos públicos. $1^{\circ}$. ed. Leme/SP: Anhanguera Editora Jurídica, 2010. p. 301.
} 
por adjudicação "Ato de adjudicar. adjudicar -Conjugar.vtr .1.Dir.Declarar quem é que tem direito a. 2.Por ext.Entregar em praça ao maior licitante. 3. Conferir (a quem de direito)" ${ }^{\prime 3}$.

Marçal Justen Filho apresenta três interessantes diferenças da adjudicação quanto a Lei geral de licitação:

$1^{\circ}$ - na ausência de recurso, a adjudicação incumbirá ao próprio pregoeiro,... Mas se houver recurso a adjudicação incumbirá a autoridade competente; $2^{\circ}$ $\mathrm{o}$ adjudicatório será obrigatoriamente convocado para assinar o contrato... Logo a adjudicação não gera simples expectativa de direito, mas produz $\mathrm{o}$ nascimento do direito a ser contratado; e $3^{\circ}$ - a adjudicação não libera os demais licitantes dos efeitos das respectivas propostas ${ }^{34}$.

Realizada a homologação, o adjudicatório é convocado para assinar o contrato ou a ata de registro de preços, dentro do prazo estipulado no edital, momento em que é exigida a comprovação da habilitação, segundo os parágrafos $1^{\circ}$ e $2^{\circ}$.

Caso o vencedor não comprove a habilitação ou recusa assinar o contrato ou a ata de registro de preços injustificadamente, outro licitante poderá ser chamado dentro da ordem da classificação, comprovando os requisitos da habilitação e realizado a negociação, assinar o contrato ou a ata de registro de preço, e as multas previstas no edital e no contrato são aplicadas, conforme $\S 3^{\circ}$. E o prazo para validade das propostas é de sessentas dias, exceto se o edital dispuser outra regra, segundo $\S 4^{\circ}$.

O convocado que não assina o contrato ou a ata de registro de preços, não entrega a documentação exigida no edital ou apresenta documentação falsa, retarda a execução do objeto, não mantiver a proposta, fraudar a execução do contrato, agir de modo inidôneo, cometer fraude fiscal e falsas declarações, com a União fica impedido de licitar e contratar, além do descredenciamento, além das multas previstas no edital e no contrato, conforme art. 28. E todas as penalidades devem ser registradas no

${ }^{33}$ Disponível em: <http://www.ambito-juridico.com.br/site/index.php?n_link=revista_artigos_leitura\&artigo_id=7924>. Acesso em: 13 Ago 2015.

${ }^{34}$ JUSTEN FILHO, Marçal. Pregão: (comentários à legislação do pregão comum e eletrônico). $1^{\circ}$. ed. São Paulo: Dialética, 2001. p. 136 - 137. 
SICAF, segundo o § único. "É instaurado processo administrativo, garantidos o contraditório e ampla defesa" ${ }^{35}$, como diz Diógenes Gasparini.

O art. 29 trata da revogação e anulação do procedimento administrativo. Benedicto de Tolosa fillho apresenta a diferença entre os dois: "a revogação ocorre por conveniência da Administração Pública e a anulação pela ocorrência de vício no ato administrativo, que o torna insusceptível de produzir efeito" 36 .

Estas são as etapas do procedimento, finalizando com a anulação ou revogação de todo o procedimento licitatório.

O pregoeiro, segundo o $\S$ único do art. $7^{\circ}$ do Decreto ${ }^{\circ} 3.555 / 00$, "Somente poderá atuar como pregoeiro o servidor que tenha realizado capacitação específica para exercer a atribuição"37.

Cabe à autoridade competente designar o pregoeiro, sendo servidores do órgão ou entidade promotora da licitação ou órgão e entidade integrante do SICAF. No Ministério da Defesa compete aos militares, conforme o art. 10, caput e $\S 2^{\circ}$ do Decreto $n^{\circ} 5.450 / 05$.

O período da designação do pregoeiro é de um ano, admitindo reconduções, segundo o $\S 4^{\circ}$ do art. 10. E as atribuições do pregoeiro estão indicadas nos incisos do art. 11:

I - Coordenar o processo licitatório; II - Receber, examinar e decidir as impugnações e consultas ao edital, apoiado pelo setor responsável pela sua elaboração; III - Conduzir a sessão pública na internet; IV - Verificar a conformidade da proposta com os requisitos estabelecidos no instrumento convocatório; V - Dirigir a etapa de lances; VI Verificar e julgar as condições de habilitação; VII Receber, examinar e decidir os recursos, encaminhando à autoridade competente quando

${ }^{35}$ GASPARINI, Diógenes. Direito Administrativo. 14. ed. São Paulo: Atlas, 2009. p. 589.

${ }^{36}$ TOLOSA FILHO, Benedicto de. Pregão - Uma Nova Modalidade de Licitação, $5^{\mathrm{a}}$ edição. Forense, 2012. Disponível em: <http://integrada.minhabiblioteca.com.br/books/978-85-309-4397-4/page/161>. Acesso em: 15 Ago 2015.

${ }^{37}$ BRASIL. Decreto 3.555/00. Aprova o Regulamento para a modalidade de licitação denominada pregão, para aquisição de bens e serviços comuns. Art. $7^{\circ}, \S$ único. 
manifestar sua decisão; VIII - Indicar o vencedor do certame; IX - Adjudicar o objeto, quando não houver recurso; X - Conduzir os trabalhos da equipe de apoio; XI - Encaminhar o processo devidamente instruído à autoridade superior e propor a homologação ${ }^{38}$.

Para que o pregoeiro consiga realizar todas as suas obrigações exige-se que o mesmo tenha conhecimento de como o sistema funciona. Deve ter cautela nas decisões sobre os recursos, pois pode ser encaminhado para a autoridade superior deliberar. Quanto a adjudicação nem sempre recairá ao pregoeiro, pois também compete a autoridade competente.

Os afazeres da equipe de apoio o pregoeiro deve prescrever as tarefas para o bom andamento do processo licitatório. E concluso todo o procedimento incumbe ao pregoeiro encaminhar para a autoridade competente homologar.

A habilitação também conhecida como qualificação, "é a fase do procedimento em que se analisa a aptidão dos licitantes" ${ }^{\text {"39 }}$. Esta aptidão é feita através do exame quanto à habilitação jurídica, técnica, econômicofinanceira, fiscal entre outras como descreve os incisos do art.14 do Decreto 5.450/05:

Art.14. Para habilitação dos licitantes, será exigida, exclusivamente, a documentação relativa:I- à habilitação jurídica;II - à qualificação técnica;III - à qualificação econômico-financeira;IV - à regularidade fiscal com a Fazenda Nacional, o sistema da seguridade social e o Fundo de Garantia do Tempo de Serviço - FGTS;V - à regularidade fiscal perante as Fazendas Estaduais e Municipais, quando for o caso; e

${ }^{38}$ BRASIL. Decreto 5.450/05. Regulamenta o pregão, na forma eletrônica, para aquisição de bens e serviços comuns, e dá outras providências. Art. 11.

${ }^{39}$ MELLO, Celso Antônio Bandeira de. Curso de Direito Administrativo. 31. ed. São Paulo: Malheiros editores LTDA, 2014. p. 598. 
VI - ao cumprimento do disposto no incisoXXXIII do art. $7^{\circ}$ da Constituiçãoe noinciso XVIII do art. 78 da Lei ${ }^{\circ} 8.666$, de $1993^{40}$.

Quanto à habilitação jurídica, o art. 28 da Lei 8.666/93 restringe o rol da documentação. O objetivo aqui é comprovar a existência legal do licitante, se é pessoa física ou jurídica, empresa, sociedade, a denominação, domicilio ou sede entre outros. Quanto à qualificação técnica o art. 30 da Lei 8.666/93 que estabelece a documentação. Benedicto de Tolosa Filho diz que a "a exigência de qualificação técnica deve se restringir à demonstração de que o licitante está apto a executar contrato cujo objeto tenha essas características, visto que a parte final do inciso XXI do art. 37 da Constituição da República estabelece essa regra" ${ }^{\text {"1 }}$.

$\mathrm{Na}$ qualificação econômico-financeira, o art. 31 da Lei 8.666/93 que dispõe os principais documentos. O único intuito é demonstrar que o licitante tem condições econômico-financeiras para executar o objeto pretendido.

Em relação à regularidade fiscal com a Fazenda Nacional, o sistema da seguridade social e o Fundo de Garantia do Tempo de Serviço - FGTS; e a regularidade fiscal perante as Fazendas Estaduais e Municipais estão dispostos no art. 29 da Lei 8.666/93. Quando for Fazenda Pública Federal, a comprovação tem que ser feita independente do tipo de atividade exercida. Quando for à esfera Estadual exige a comprovação de pessoal física ou jurídica e na esfera Municipal à comprovação de quem prestam serviço.

Quando a participação na licitação for de empresas estrangeira, para a habilitação exigem-se documentos equivalentes e autenticados pelos consulados ou embaixadas traduzidos por tradutor juramentado no Brasil, conforme o art. 15 do Decreto 5.450/05. Sidney Bittencourt ainda diz que os documentos devem passar pelo crivo do consulado brasileiro:

\footnotetext{
${ }^{40}$ BRASIL. Decreto 5.450/05. Regulamenta o pregão, na forma eletrônica, para aquisição de bens e serviços comuns, e dá outras providências. Art. 14.

${ }^{41}$ TOLOSA FILHO, Benedicto de. Pregão - Uma Nova Modalidade de Licitação, $5^{\mathrm{a}}$ edição. Forense, 2012. VitalBook file. Disponível em: <http://integrada.minhabiblioteca.com.br/books/978-85-309-4397-4/page/73>. Acesso em: 16 Ago 2015.
} 
De acordo com o previsto na Convenção de Viena, os documentos devem ser "consularizados", isto é, passarem pelo crivo do consulado brasileiro (ou embaixada) dentro da jurisdição de sua emissão. Autenticação consular não é o mesmo que reconhecimento de assinatura (o "reconhecimento de firma" brasileiro). A autenticação dos consulados atesta, isto sim, que os documentos têm valor probatório da idoneidade do licitante para fins de habilitação ${ }^{42}$.

No caso da participação de empresas que tem o regime de consórcio, esta participação tem que estar expressa no edital do pregão. Entende-se que consórcio é uma associação de várias empresas para participar da licitação, o art. 16 do Decreto trata do tema.

Dentre estes critérios, vale ressaltar que o consórcio de empresas é utilizado quando uma única empresa dificilmente conseguiria executar o objeto da licitação. E a formalização do contrato tem que ocorrer antes da celebração do contrato.

\section{CONCLUSÃO}

Em virtude do que foi mencionado no trabalho acima, percebese que a modalidade pregão eletrônico dentro da licitação, é uma ferramenta atual para a Administração Pública como também a sociedade.

O meio utilizado, o sistema de informação, o meio eletrônico, a internet, hoje a ferramenta de comunicação mais utilizada no mundo pela sociedade e os órgãos públicos.

Importante é atentar ao significado de bens e serviços "comuns", algo que o mercado oferece que possa ser substituído por outro que tenha a mesma qualidade e eficiência. É inaplicável na contratação de obras de engenharia. E é uma modalidade de licitação somente no tipo preço, e não tipo técnica

As demais modalidades apresentadas no trabalho tem eficiência dentro da licitação, mas apresentam uma lacuna ou obscuridade em seus

\footnotetext{
${ }^{42}$ BITTENCOURT, Sidney. Pregão Eletrônico: Decreto ${ }^{\circ} 5.450$ de 31 de maio de 2005 , Lei ${ }^{\circ} 10.520$ de 17 de julho de 2002. $2^{\circ}$. ed. Rio de Janeiro: Temas e Ideias, 2005. p 91.
} 
regulamentos, uma licitação demorada, burocracia para participação, gastos tanto para a Administração quanto para os licitantes, os procedimentos não têm transparência, que gera fraude e corrupção.

E a modalidade pregão eletrônico proporcionou aos órgãos da Administração à realização da licitação de forma econômica, um procedimento mais célere com a inversão das fases, diminuindo a burocracia no processo; a transparência que é concedida a todos os cidadãos atendendo com rigor aos princípios da economicidade, eficiência (celeridade), competitividade e publicidade (transparência).

O pregoeiro, que é um servidor público que tem que se capacitar através de cursos, seminários, entre outros para estar apto para a atividade é de suma importância.

Como ponto negativo, na modalidade pregão eletrônico pode ser apontado à vulnerabilidade do sistema quanto a empresas que em conjunto tem a intenção de corromper o caráter que a modalidade emprega. Mas fica a certeza que a implantação da mesma, veio a favorecer a Administração Pública e a sociedade.

Assim, a modalidade pregão eletrônica tende a ser mais utilizada (no que for cabível a contratação de bens e serviços comuns), melhorando o trabalho do Poder Público no quesito licitação e a fiscalização quanto a atividades fraudulentas e corruptas tanto internas e externas.

\section{REFERÊNCIAS}

AMORIM, Gustavo Rodrigues. Licitação Eletrônica - Pregão Eletrônico: o marco normativo da tecnologia da informação nos contratos públicos. $1^{\circ}$. ed. Leme/SP: Anhanguera Editora Jurídica, 2010.

ARAÚJO. Edmir Netto de. Curso de direito administrativo. 6. ed. São Paulo: Saraiva, 2013. VitalBook file. Disponível em: $<$ http://integrada.minhabiblioteca.com.br/books/9788502220362/pa ge/553>. Acesso em: 9abr. 2015.

BITTENCOURT, Sidney. Pregão Eletrônico: Decreto ${ }^{\circ} 5.450$ de 31 de maio de 2005, Lei $n^{\circ} 10.520$ de 17 de julho de 2002. $2^{\circ}$. ed. Rio de Janeiro: Temas e Idéias, 2005.

BRASIL. Constituição da República Federativa do Brasil de 1988. Art. $7^{\circ}$, XXXIII. 
. Decreto 4.358/02. Regulamenta a Lei no 9.854, de 27 de outubro de 1999, que acrescentou os incisos V ao art. 27 e XVIII ao art. 78 da Lei no 8.666, de 21 de junho de 1993, referente ao cumprimento do disposto no inciso XXXIII do art. 7o da Constituição.

. Decreto 5.450/05. Regulamenta o pregão, na forma eletrônica, para aquisição de bens e serviços comuns, e dá outras providências.

. Lei 8.666/93. Lei das licitações.

COSTA, Elisson Pereira da. Coleção saberes do direito; v. 33 - Direito administrativo III : bens públicos, licitação, contratos administrativos e intervenção do Estado na propriedade privada, Saraiva, 2012. VitalBook file. Disponível em: <http://integrada.minhabiblioteca.com.br/books/9788502178656/pa ge/48>. Acesso em: 06 Ago 2015.

DI PIETRO, Maria Sylvia Zanella. Direito administrativo. 27. ed. São Paulo: Atlas, 2014. p. 373.

Disponível

em:

$<$ http://www.ambito-

juridico.com.br/site/index.php/?n_link=revista_artigos_leitur a\&artigo_id=13610\&revista_caderno=4>. Acesso em 16 Set 2015.

Disponível

em:

$<$ http://www.ambito-

juridico.com.br/site/index.php?n_link=revista_artigos_leitura\&arti

go_id=7924>. Acesso em: 13 Ago 2015.

Disponível

em:

<http://www.comprasgovernamentais.gov.br/arquivos/manuai

s/manual_pregao_eletronico_versao_do_fornecedor_julho_20 06.pdf>. Acesso em: 16 Set 2015.

Disponível em: <http://www.governoeletronico.gov.br/acoes-eprojetos/compras-governamentais/fornecedores/sistema-decadastramento-unificado-de-fornecedores-2013-sicaf>. Acesso em: 29 Jul 2015.

GASPARINI, Diógenes. Direito Administrativo. 14. ed. São Paulo: Atlas, 2009.

JUSTEN FILHO, Marçal. Pregão: (comentários à legislação do pregão comum e eletrônico). $1^{\circ}$. ed. São Paulo: Dialética, 2001.

MEIRELLES, Hely Lopes. Licitação e contrato administrativo. 9. ed. São Paulo: Revistas dos Tribunais, 1990.

MELLO, Celso Antônio Bandeira de. Curso de Direito Administrativo. 31. ed. São Paulo: Malheiros editores LTDA, 2014. 
MUKAI, Toshio. O novo estatuto jurídico das licitações e contratos públicos: comentário à Lei 8.666/93, com as alterações promovidas pela Lei 8.883/94. 3. ed. São Paulo: Revista dos Tribunais, 1994.

TOLOSA FILHO, Benedicto de. Pregão - Uma Nova Modalidade de Licitação, $5^{\text {a }}$ edição. Forense, 2012. VitalBook file. Disponível em: $<$ http://integrada.minhabiblioteca.com.br/books/978-85-309-43974/page/60>. Acesso em: 06 Ago 2015. 